Kumawula, Vol. 3, No.2, Agustus 2020, Hal 272 - 279

DOI: https://doi.org/10.24198/kumawula.v3i2.27481

ISSN 2620-844X (online)

Tersedia online di http://jurnal.unpad.ac.id/kumawula/index

\title{
PENGEMBANGAN SDM JURNALISTIK TELEVISI BAGI SISWA SMA DI KOTA TANGERANG SELATAN, BANTEN
}

\author{
Syaiful Halim \\ Universitas Dian Nusantara \\ syaiful.halim@undira.ac.id
}

\begin{abstract}
ABSTRAK
Siswa SMA merupakan bagian dari khalayak potensial yang setiap saat menerima berbagai informasi dari media televisi dan media lainnya. Pada masa sekarang, mereka juga dihadapkan pada kecenderungan untuk memproduksi paket-paket informasi melalui media sosial, meski sesungguhnya mereka tidak memiliki pengetahuan yang memadai untuk melaksanakan kegiatan produksi paket-paket informasi. Kegiatan PPM ini perlu dilakukan sebagai pembekalan pengetahuan dan keterampilan bidang jurnalistik televisi bagi siswa SMA di Tangerang Selatan, Banten. Tujuan penulisan makalah ini, mendeskripsikan hasil kegiatan pengabdian kepada masyarakat berupa pengembangan sumber daya manusia bidang jurnalistik televisi bagi siswa-siswa SMA di Kota Tangerang Selatan, Banten, dalam bentuk perkuliahan tatap muka dan online melalui aplikasi zoom. Luaran kegiatan PPM ini adalah peningkatan pengetahuan di bidang jurnalistik televisi pada siswa SMA di Tangerang Selatan, Banten, dari sebelumnya tidak memiliki pengetahuan tentang kegiatan jurnalistik televisi menjadi memahami rangkaian kegiatan kegiatan jurnalistik televisi.
\end{abstract}

Kata kunci: pengembangan sdm; jurnalistik televisi, jurnalisis televisi; siswa sma; paket informasi.

\section{PENDAHULUAN}

Ketika media baru dengan keluarbiasaan media sosial-nya terus membombardir khalayak, maka harus diakui bahwa abad ini memang mulai menjadi milik media baru. Bahkan, harus diakui, kehandalan telepon selular cerdas telah menggantikan perangkat dan peran media lama, seperti televisi, radio, juga majalah dan surat kabar. Bahkan, dalam konteks Revolusi Industri 4.0, fakta ini juga menjadi pembuktian bahwa media baru terus memperkuat kekokohan hegemoninya dan kian tidak sabar untuk menggantikan kedigjayaan media lama. Situasi ini dengan sendirinya menggeser realitas baru bahwa kekuatan media sosial telah mengubah khalayak yang semula duduk pasif menerima pesan apa pun dari pengirim pesan (katakanlah media lama) menjadi pengirim pesan yang agresif untuk merekam, mengonstruksi, dan mendistribusikan pesan melalui medium bernama smarphone (Halim, 2019). 
Di sisi lain, ada juga realitas yang perlu dicermati, yakni fenomena keberlimpahan konten-konten dari media baru dengan segala “keunikan”nya, yang belakangan menjadi ancaman serius bagi keberadaan karya-karya jurnalistik (Halim, 2020). Bukan rahasia lagi, keluarbiasaan media online telah berhasil menggusur keberadaan sejumlah media cetak hingga benar-benar harus gulung tikar. Fenomena ini bukan hanya terjadi di Indonesia, tapi juga di negara-negara maju. Jalan pintas yang dilakukan oleh para pengelola media cetak yang masih ingin tetap memproduksi karya-karya jurnalistik adalah migrasi dari media cetak menjadi media online, atau bagi yang memiliki modal lebih, media cetaknya berjalan beriringan dengan media versi online-nya.

Lantas bagaimana dengan media televisi?

Banyak fenomena menarik terkait keberadaan karya-karya jurnalistik di media televisi. Atas nama strategi komodifikasi, program berita bisa menghadirkan konten-konten bernuansa infotainment (Halim, 2013); stasiun televisi berpihak kepada kepentingan kelompok politik tertentu (Halim, 2018); bahkan stasiun televisi tidak menyiarkan kontenkonten tertentu, meski terbilang memiliki nilai berita tinggi. Stasiun televisi yang sangat berorientasi mengejar keuntungan (market orientation) harus melikuidasi program beritanya demi memberikan slotnya kepada program-program hiburan semacam sinetron atau reality show—contoh kasusnya adalah stasiun SCTV yang melikuidasi program Liputan 6 Petang.

Dengan fenomena-fenomena ini, bisa dikatakan, keberadaan media baru dengan kekuatan media sosial-nya memberikan kontribusi besar atas "keberadaan” karya-karya jurnalistik pada era digital. Kata "keberadaan” yang dimaksud dari pernyataan ini adalah kelangsungan konten-konten berupa karya-karya jurnalistik di media cetak dan media televisi; dan pada akhirnya, masa depan konten-konten berupa karya-karya jurnalistik di media cetak dan media televisi. Singkatnya, keberadaan media baru dengan kekuatan media sosial-nya memberikan kontribusi besar atas ancaman keruntuhan karya-karya jurnalistik secara kuantitas dan kualitas.

Keganduhan semacam inilah yang belakangan menerpa khalayak di Tanah Air, termasuk di antaranya para siswa SMA. Mereka juga merupakan bagian dari khalayak potensial yang setiap saat menerima berbagai informasi dari media televisi dan media lainnya. Bahkan, saat ini mereka juga dihadapkan pada kecenderungan untuk memproduksi paket- 
paket informasi melalui media sosial, meski sesungguhnya mereka tidak memiliki pengetahuan yang memadai untuk melaksanakan kegiatan produksi paket-paket informasi. Pada akhirnya, mereka pun menjadi bagian dari produsen yang memproduksi konten-konten dengan kegaduhan.

Agar para siswa SMA tidak menjadi "korban” atas keganduhan yang terjadi di media aras utama atau media sosial, sekaligus tidak menjadi produsen paket-paket informasi yang cenderung membangun kegaduhan, maka dibutuhkan sebuah ruang pembelajaran untuk memberikan pengetahuan dan pemahaman, bahkan bisa mempraktikkan kegiatan-kegiatan produksi paket-paket informasi, yang tidak bernuansa membangun kegaduhan. Dalam konteks ini, pembelajaran materi-materi jurnalistik televisi menjadi jawabannya. Karena, materi-materi jurnalistik televisi merupakan pengetahuan dasar dalam pengembangan kontenkonten kreatif dalam bentuk audio-visual di media televisi dan media sosial semacam YouTube.

Beranjak dari pemikiran di atas, penulis menggelar kegiatan pengabdian kepada masyarakat (selanjutnya disebut PPM) dalam bentuk kegiatan perkuliahan jurnalistik televisi kepada siswa-siswa SMA secara tatap muka selama satu semester (16 pertemuan). Selain memberikan pengetahuan dan pemahaman, bidang jurnalistik televisi, dari kegiatan ini juga diberikan pembekalan keterampilan atau pengetahuan secara praktika terkait kegiatan reportase, produksi, dan distribusi, berita untuk media televisi. Dengan demikian, mereka bukan hanya akan memiliki pengetahuan dan pemahaman yang lebih baik tentang kegiatan jurnalistik televisi, tapi juga mampu memproduksi dan mendistribusikan berita televisi atau paket-paket informasi dalam bentuk audio-visual untuk media televisi atau media sosial semacam YouTube.

Untuk melaksanakan kegiatan PPM ini dibutuhkan kompetensi di bidang komunikasi massa, khususnya jurnalistik televisi. Lebih khusus lagi, mentor dalam kegiatan bukan sekadar menguasai teori-teori jurnalistik televisi, tapi juga kegiatan praktik jurnalistik televisi. Karena, dalam kegiatan ini, para peserta akan menerima pengetahuan dan pemahaman tentang keberadaan jurnalistik televisi, para jurnalis televisi yang bekerja untuk media televisi, hingga keterampilan melakukan kegiatan reportase di berbagai bidang redaksi, penulisan naskah berita televisi, produksi paket-paket berita untuk media televisi, hingga kegiatan distribusi berita televisi melalui media streaming (sebagai pengganti media televisi). 
Artinya, porsi perkuliahan di dalam kecil relatif lebih kecil dibandingkan porsi pendampingan dalam kegiatan reportase, produksi, dan distribusi, paket-paket informasi berbentuk audiovisual untuk media televisi atau media sosial.

\section{METODE PELAKSANAAN}

Kegiatan PPM ini dilakukan di dalam kelas dan luar kelas. Kegiatan di dalam kelas berupa perkuliahan sejumlah materi yang bersifat teori sambil menjelaskan contoh-contoh kasus yang terjadi di media televisi dan media sosial semacam YouTube sepanjang enam pertemuan. Sedangkan kegiatan di luar kelas berupa pendampingan kegiatan reportase di luar kelas, pendampingan produksi berita televisi di ruang redaksi, dan kegiatan distribusi paketpaket berita melalui kanal khusus di media sosial YouTube di ruang redaksi, sepanjang delapan pertemuan. Total kegiatan PPM ini membutuhkan waktu 16 pertemuan, yakni 14 pertemuan untuk kegiatan perkuliahan di dalam dan luar kelas, serta dua pertemuan untuk evaluasi.

Pada tahap kegiatan praktik berupa reportase, produksi, dan distribusi, telah menggunakan perlengkapan produksi seperti perlengkapan syuting (kamera, tripod, dan michrophone), perlengkapan penyuntingan gambar (laptop dengan aplikasi penyuntingan gambar), hingga perlengkapan streaming (laptop yang disertai jaringan internet). Selain menggunakan perlengkapan produksi milik Komunitas M-DOCS, kegiatan PPM ini juga memanfaatkan perlengkapan produksi milik peserta kegiatan.

\section{HASIL DAN PEMBAHASAN}

Persiapan kegiatan PPM ini dilaksanakan pada akhir Februari 2020 di kantor Komunitas M-DOCS di Tangerang Selatan, Banten, yang ditandai dengan kegiatan penyusunan rencana pembelajaran semester (RPS) dan modul perkuliahan, publikasi penerimaan peserta kegiatan melalui media sosial, dan penerimaan peserta kegiatan. Hasil seleksi atas sejumlah peserta yang mendaftar secara online adalah 10 peserta. Jumlah ini mengacu pada ketersediaan tempat dan fasilitas kegiatan perkuliahan.

Sementara kegiatan PPM dilaksanakan pada Maret-Juni 2020 di kantor Komunitas MDOCS di Tangerang Selatan, Banten, berupa perkuliahan di dalam kelas dan juga secara online melalui aplikasi zoom. Kegiatan perkuliahan di dalam kelas sempat dilaksanakan sebanyak empat pertemuan. Setelah pandemi Covid-19 melanda dan kebijakan PSBB diberlakukan, kegiatan PPM sempat terhenti selama dua pekan. Pada akhirnya diputuskan, 
seluruh kegiatan PPM dilanjutkan secara online melalui aplikasi zoom, dengan meniadakan kegiatan pendampingan reportase, produksi, dan distribusi, atas paket-paket berita yang akan diproduksi, juga kegiatan evaluasi. Artinya, total dibutuhkan 10 pertemuan lagi untuk menuntaskan seluruh kegiatan.

\section{Gambar 1: Kegiatan Perkuliahan di Dalam Kelas} (Foto: Syaiful Halim).
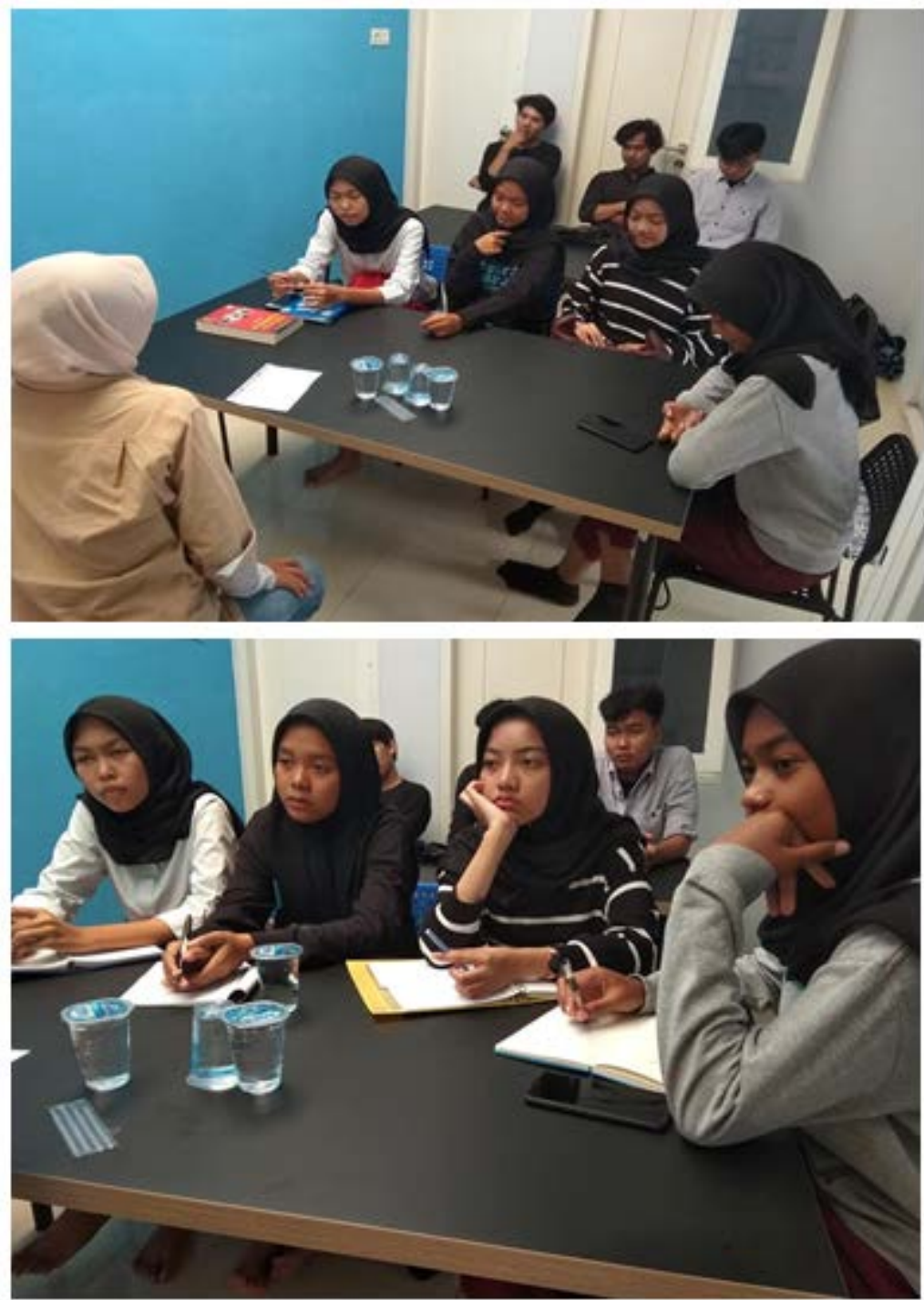

Dengan demikian, seluruh materi perkuliahan, seperti fenomena media televisi, fenomena jurnalis televisi, fenomena berita televisi, teknik reportase untuk media televisi, teknik penulisan naskah berita televisi, juga teknik produksi berita untuk media televisi, tetap bisa diberikan tapi sebatas teori. Meski demikian, sepuluh peserta terpilih tetap mengikuti seluruh kegiatan dengan penuh antuasias, dan memiliki kemauan yang tinggi untuk mendapatkan pengetahuan dan pemahaman tentang kegiatan jurnalistik televisi. Catatan kecil 
membangun optimistis bahwa luaran kegiatan PPM ini berupa peningkatan pengetahuan dan pemahaman atas kegiatan jurnalistik televisi pada siswa SMA di Tangerang Selatan, Banten, tercapai.

Semula luaran dari kegiatan PPM ini adalah peningkatan pengetahuan, pemahaman, dan keterampilan, di bidang jurnalistik televisi, yang ditunjukkan dalam luaran berupa produksi dan distribusi karya-karya jurnalistik televisi secara streaming melalui media sosial YouTube. Selain itu, para peserta juga diwajibkan untuk mengikuti kegiatan evaluasi kegiatan perkuliahan berupa ujian tengah semester dan ujian akhir semester. Namun, hambatan peristiwa pandemi Covid-19 dan kebijakan PSBB membuat target luaran kegiatan PPM pun dikurangi menjadi sebatas peningkatan pengetahuan dan pemahaman di bidang jurnalistik televisi.

Gambaran rutinitas media seluruh langkah di atas Penulis sederhanakan dalam rupa Model Kegiatan Pengabdian kepada Masyarakat - perhatikan Gambar 2.

Gambar 2: Model Kegiatan Pengabdian kepada Masyarakat (Gambar: Syaiful Halim).

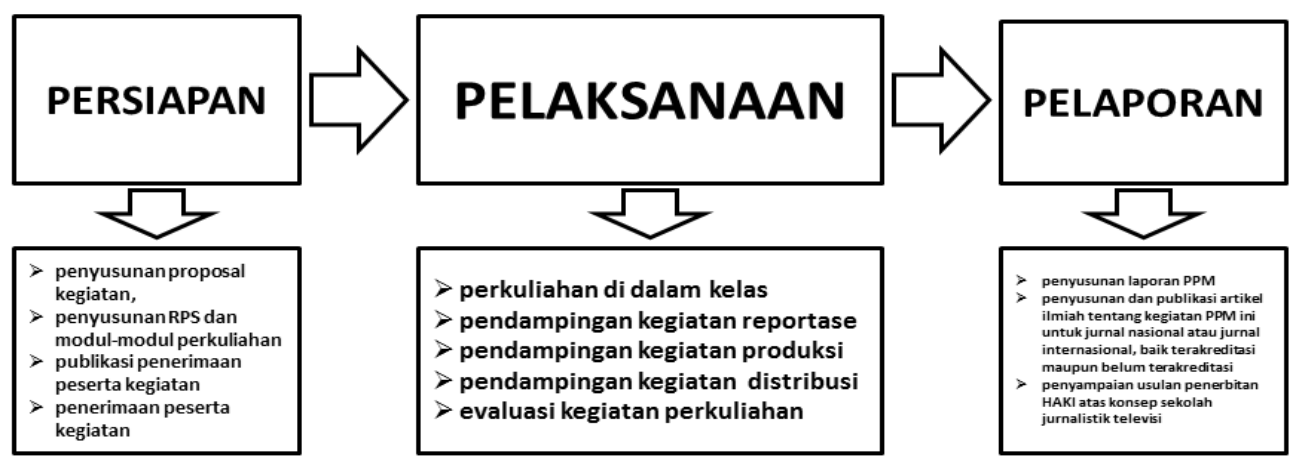

Seperti telah dijelaskan di atas, terkait peristiwa pandemi Covid-19 dan kebijakan PSBB, sehingga kegiatan dilanjutkan secara online dengan menggunakan aplikasi zoom. Pada akhirnya, pengurangan atau perubahan kegiatan terjadi pada tahap pelaksanaan, dengan meniadakan kegiatan pendampingan kegiatan reportase, kegiatan produksi, kegiatan distribusi, dan kegiatan evaluasi. Sedangkan kegiatan pada tahap perencanaan dan pelaporan bisa dilaksanakan sesuai rencana.

Mengacu pada luaran dari solusi yang ditawarkan, yakni pengembangan sumber daya manusia (SDM) bidang jurnalitik televisi pada siswa SMA di Kota Tangerang Selatan, Banten, kegiatan PPM ini menunjukkan hasil yang menggembirakan. Bahwa terjadi peningkatan pengetahuan bidang jurnalitik televisi pada sepuluh peserta terpilih usai 
mengikuti kegiatan PPM, dari sebelumnya tidak memiliki pengetahuan tentang kegiatan jurnalistik televisi menjadi memahami rangkaian kegiatan kegiatan jurnalistik televisi. Indikator atas pemahaman ini didapat dengan cara menguji pengetahuan dan pemahaman peserta saat perkuliahan secara online berlangsung.

\section{RENCANA LANJUTAN}

Masih dibutuhkan ruang lain, katakanlah kegiatan PPM lanjutan, untuk lebih meningkatkan pengetahuan, pemahaman, dan keterampilan para peserta kegiatan PPM kali ini, persisnya berupa pendampingan dalam kegiatan reportase, kegiatan produksi, kegiatan distribusi, dan juga menjalankan kegiatan evaluasi. Pada masa mendatang, Penulis akan mengajak ke-10 peserta kegiatan PPM kali ini, untuk mengikuti kegiatan PPM lanjutan berupa Pengembangan SDM Bidang Jurnalistik Televisi Tingkat Lanjutan untuk Siswa SMA di Tangerang Selatan, Banten, dengan materi prioritas pada peningkatan keterampilan kegiatan jurnalistik televisi. Fokus kegiatan PPM yang dimaksud adalah praktik reportase, praktik produksi, dan praktik distribusi secara streaming melalui media sosial YouTube.

\section{KESIMPULAN}

Berikut ini kesimpulan atas kegiatan PPM yang telah penulis lakukan:

a. Kegiatan pengabdian kepada masyarakat berupa pengembangan sumber daya manusia (SDM) bidang jurnalistik televisi untuk siswa SMA di Tangerang Selatan, Banten, dilaksanakan pada Maret-Juni 2020 di kantor Komunitas M-DOCS di Tangerang Selatan, Banten, berupa perkuliahan di dalam kelas dan juga secara online melalui aplikasi zoom. Meski demikian, sepuluh peserta terpilih tetap mengikuti seluruh kegiatan secara antuasia hingga tuntas.

b. Kegiatan perkuliahan di dalam kelas sempat dilaksanakan sebanyak empat pertemuan. Setelah pandemi Covid-19 melanda dan kebijakan PSBB diberlakukan, kegiatan PPM sempat terhenti selama dua pekan. Pada akhirnya diputuskan, seluruh kegiatan PPM dilanjutkan secara online melalui aplikasi zoom, dengan meniadakan kegiatan pendampingan reportase, produksi, dan distribusi, atas paket-paket berita yang akan diproduksi, juga kegiatan evaluasi. 
c. Hambatan peristiwa pandemi Covid-19 dan kebijakan PSBB membuat target luaran kegiatan PPM pun dikurangi menjadi sebatas peningkatan pengetahuan dan pemahaman di bidang jurnalistik televisi.

d. Bahwa terjadi peningkatan pengetahuan bidang jurnalitik televisi pada sepuluh peserta terpilih usai mengikuti kegiatan PPM, dari sebelumnya tidak memiliki pengetahuan tentang kegiatan jurnalistik televisi menjadi memahami rangkaian kegiatan kegiatan jurnalistik televisi. Indikator atas pemahaman ini didapat dengan cara menguji pengetahuan dan pemahaman peserta saat perkuliahan secara online berlangsung.

e. Masih dibutuhkan ruang lain, katakanlah kegiatan PPM lanjutan, untuk lebih meningkatkan pengetahuan, pemahaman, dan keterampilan para peserta kegiatan PPM kali ini, persisnya berupa pendampingan dalam kegiatan reportase, kegiatan produksi, kegiatan distribusi, dan juga menjalankan kegiatan evaluasi.

\section{DAFTAR PUSTAKA}

Halim, S. (2013). Postkomodifikasi Media: Analisis Media Televisi dengan Teori Kritis dan Cultural Studies. Yogyakarta: Jalasutra.

Halim, S. (2018). Commodification of Religious Defamation Case by BTP in Television Broadcasting Stations in Indonesia. Idealogy Journal. Vol. 3 No. 3. Perak: Universitas Teknologi Mara (UiTM), Selangor, Malaysia.

Halim, S. (2020). Dekonstruksi Figur Sayyidah Aisyah RA dalam Lagu Aisyah Istri Rasulullah: Studi Semiotika Poststrukturalis Roland Barthes. Idealogy Journal Vol. 5 No. 2. Perak: Universitas Teknologi Mara (UiTM), Selangor, Malaysia.

Halim, S. (2019). Reportase: Panduan Praktis Reportase untuk Media Televisi. Jakarta: Prenada Media Group. 